\title{
Modelling fallen branch volumes in a temperate eucalypt woodland: implications for large senescent trees and benchmark loads of coarse woody debris
}

\author{
PAUL KILLEY, CHRIS MCELHINNY, „ IAN RAYNER AND JEFF WOOD \\ The Fenner School of Environment and Society, College of Medicine, Biology E Environment, \\ Australian National University, Building 48, Linnaeus Way, Canberra, ACT 0200, Australia (Email: \\ chris.mcelhinny@anu.edu.au)
}

\begin{abstract}
Fallen branches are a substantial component of coarse woody debris and a key ecological resource. The depletion of stocks of coarse woody debris since European settlement has contributed to the degradation of Australian grassy box woodlands, including the loss of biodiversity. Restoration options for remnant woodlands include the augmentation of coarse woody debris stocks. However, the extensive modification of grassy box woodlands has left few reference sites for establishing benchmarks to guide such restoration. In this paper we demonstrate a method for predicting fallen branch debris loads in the absence of reference sites, using data from a yellow box-red gum woodland. Our methodology is in two stages: first, the total volume of branch debris under individual trees was modelled; and second, these models were applied to groups of trees to predict stand-level loads of fallen branch debris. Although the models were developed for yellow box-red gum woodlands, the methodology would be applicable to other communities that lack reference sites. Predicted benchmark loads of fallen branch debris for yellow box-red gum woodland were between $7.0 \mathrm{~m}^{3} \mathrm{ha}^{-1}$ and $11.9 \mathrm{~m}^{3} \mathrm{ha}^{-1}$. Large senescing trees contributed the bulk of fallen branch debris. Model predictions indicated a 100-cm diameter at breast height (dbh) tree was 10 times more likely to produce debris than a $50-\mathrm{cm} \mathrm{dbh}$ tree, and if debris was present a $100-\mathrm{cm} \mathrm{dbh}$ tree produced approximately 10 times the volume of branch debris produced by a $50-\mathrm{cm} \mathrm{dbh}$ tree. These results highlight the importance of large senescing trees for the production of fallen branch debris and support the keystone role of large trees within remnant woodlands, and the need to conserve these structures. Our results also support the active management of regrowth woodland stands to facilitate the progression of individual trees to maturity and senescence. In particular, thinning of regrowth stands may promote the growth of retained trees, ensuring they contribute to fallen branch debris stocks with a minimum time lag.
\end{abstract}

Key words: ecological thinning, Eucalyptus blakelyi, Eucalyptus melliodora, keystone structure, savanna, scattered tree.

\section{INTRODUCTION}

Fallen branches, fallen trees, standing dead trees and stumps, collectively known as coarse woody debris, are a key component of woodland and forest ecosystems (Harmon et al. 1986; Wall 2000; Martin \& Green 2002). A wide variety of fauna requires this resource for habitat, including birds, mammals, reptiles and invertebrates (Smith et al. 1989; Driscoll et al. 2000; Wall 2000; Mac Nally et al. 2001; Martin et al. 2004; Doerr et al. 2006; Barton et al. 2009). Coarse woody debris provides directly for the nutrition of detritivores, and indirectly for foraging fauna (Mackensen et al. 2003; Bate et al. 2004; Doerr et al. 2006; Mac Nally \& Horrocks 2007). Seedlings and cryptogams also utilize coarse woody debris and can become estab-

${ }^{\star}$ Corresponding author.

Accepted for publication November 2009. lished under the protection and microclimate it provides (Bowker 2007; Davidson et al. 2007; de Chantal \& Granström 2007). Coarse woody debris plays a key role in nutrient cycling as it contains a substantial reserve of nutrients and organic carbon (Harmon et al. 1986; Harmon \& Hua 1991; Stevens 1997; Woldendorp \& Keenan 2005). The slow decomposition of this debris ensures these resources are not readily leached, contributing to site productivity and sustaining soil organic carbon levels (Harmon \& Hua 1991; Wall 2000; Debeljak 2006). Coarse woody debris can also intercept mobilized soil particles and other organic litter, reducing erosion and loss of resources (Harmon \& Hua 1991; Tongway \& Ludwig 1996; Tinker \& Knight 2001; Woldendorp et al. 2002).

Coarse woody debris is produced by a variety of disturbance events. Wind and lightning can break branches and boles or uproot trees (Harmon et al. 1986; Maser et al. 1988; James et al. 2006). Drought, 
fire, disease, pests, suppression and senescence can cause crown dieback or the death of trees (Jacobs 1955; Pook 1985; Stevens 1997; Keane et al. 2000). Anthropogenic disturbances such as ringbarking or harvesting of tree boles can also contribute to the production of coarse woody debris (Hagan \& Grove 1999; Wall 2000; Grove \& Meggs 2003).

In eucalypt woodlands a considerable proportion of coarse woody debris occurs as fallen branches. This largely reflects two factors: first, the tendency for trees in open woodland conditions to retain large lower branches (Beadle 1981), so that a greater proportion of tree biomass is contained in branches compared with trees in denser stands (Henskens et al. 2001); and second, the fact that eucalypts are particularly prone to branch shedding because the replacement of leaves requires the growth and extension of branches (Jacobs 1955). Disturbance events such as drought, insect attack or fire may cause the death of some branches, which will weaken and become more likely to fall (Jacobs 1955). Large woodland eucalypt trees are able to survive and recover from many disturbance events until they senesce and die. Once dead, woodland eucalypt trees are likely to remain upright for considerable periods of time, reflecting their durable wood (Mackensen et al. 2003), shorter stature and larger root systems compared with trees in wetter forest ecosystems. These dead standing trees gradually shed branches, which helps sustain stocks of coarse woody debris (Vanderwel et al. 2006). Ultimately, some of these trees may fall over, so that their boles contribute large logs to coarse woody debris stocks.

Since European settlement, woodlands in southeastern Australia have been extensively modified. This has included the removal of coarse woody debris for fuel wood and to reduce wildfire hazards (Driscoll et al. 2000; Wall 2000), and the reduction of inputs of coarse woody debris through thinning of the overstorey to promote pasture growth. The consequent reduction in stocks of coarse woody debris has contributed to the degradation of these woodlands, particularly the loss of biodiversity (Yates \& Hobbs 1997; Wall 2000).

Yellow box-red gum woodland is an important component of the mosaic of woodland communities in south-eastern Australia (Beadle 1981; ACT Government 2004). This community consists of an overstorey dominated by yellow box (Eucalyptus melliodora Cunn. ex Schauer) and Blakely's red gum (Eucalyptus blakelyi Maiden) with a diverse understorey dominated by grasses (ACT Government 2004). It is estimated that less than $5 \%$ of the pre-European extent of yellow box-red gum woodlands remains (Landsberg 2000), and McElhinny et al. (2006) could find no unmodified examples in a $15000-\mathrm{km}^{2}$ study area located within the South-eastern bioregion of Australia. This vegetation community is now recognized by three governments as an endangered ecological community (NSW

(C) 2010 The Authors

Journal compilation (C) 2010 Ecological Society of Australia
Scientific Committee 2002; ACT Government 2004; Department of the Environment Water Heritage and the Arts 2008). The rare and highly modified nature of remnant yellow box-red gum woodlands means that restoration strategies are central to conservation efforts, including the augmentation of coarse woody debris stocks (ACT Government 2004; Prober \& Thiele 2005). The implementation of this strategy, however, raises a fundamental question: how much coarse woody debris should there be in yellow box-red gum woodlands?

In Australia, the condition of ecological communities before European settlement is typically considered the benchmark condition (Lunt 2002; Oliver et al. 2002; Parkes et al. 2003; Department of the Environment and Water Resources 2007). Benchmark values are commonly established by measuring the ecological variable of interest at a reference site known to be unmodified or little modified since European settlement (Prober et al. 2002; Mac Nally et al. 2002b; Parkes et al. 2003; Lester et al. 2006; McElhinny et al. 2006). However, this approach is of little use in landscapes where unmodified examples of a vegetation community no longer exist.

To address this situation, alternative approaches have been suggested for establishing benchmark loads of coarse woody debris. Manning et al. (2007) used van Wagner's (1968) line intersect method and a sampling approach deliberately biased towards areas where debris was present to estimate 'plausible' benchmark coarse woody debris loads for yellow box-red gum woodlands. Gibbons et al. (2008) measured ecological variables including coarse woody debris loads and indices of modification across a number of communities in New South Wales including sites in yellow box-red gum woodlands. The ecological variables were modelled according to the level of modification allowing minimally modified conditions to be estimated.

These two approaches produced very different estimates for the benchmark coarse woody debris load in yellow box-red gum woodlands. Manning et al. (2007) reported median loads of $19.3 \mathrm{~m}^{3} \mathrm{ha}^{-1}$, with a mean of $34.0 \mathrm{~m}^{3} \mathrm{ha}^{-1}$ and a range of $3.0 \mathrm{~m}^{3} \mathrm{ha}^{-1}-247.2 \mathrm{~m}^{3} \mathrm{ha}^{-1}$, whereas Gibbons et al. (2008), estimated loads of $8.2 \pm 2.6 \mathrm{~m}^{3} \mathrm{ha}^{-1}$. In this paper, we address the discrepancy between these estimates by developing a new methodology for estimating the production of coarse debris via fallen branch debris. This approach will provide conservative estimates of coarse woody debris stocks because it does not include the contribution of fallen tree boles.

Our methodology is based on the following hypotheses:

1. The volume of fallen branch debris associated with an individual tree can be modelled in terms of simple variables describing tree size, condition and landscape position (tree-level model).

doi:10.1111/j.1442-9993.2010.02107.x 
2. The volume of fallen branches in a stand of given structure can be estimated using stand scale distributions of the tree-level model variables (standlevel model).

3. Benchmark volumes of fallen branch debris can be estimated by applying benchmark estimates of the stand-level model variables.

\section{METHODS}

A variety of dimensions have been used to define the coarse fraction of woody debris (Woldendorp et al. 2004). For the purposes of this study, we set the minimum small end diameter for branch debris at $10 \mathrm{~cm}$ and the minimum length at $1 \mathrm{~m}$. This was in line with the definition used by Manning et al. (2007) and Gibbons et al. (2008). We modelled the volume of fallen branch debris in two stages. First the total volume of fallen branches under individual trees (tree debris) was modelled. This involved measuring a large number of individual fallen branches and utilized a previously developed allometric to rapidly and accurately estimate branch volume (see Killey 2008). In the second stage the tree debris model was applied to groups of trees to predict stand-level loads of fallen branch debris.

\section{Study site}

The study was conducted between March and May 2008 at the Goorooyarroo Nature Reserve in the Australian Capital Territory (ACT) (Fig. 1). This reserve is approximately 700 ha in size, and although managed as a leasehold grazing property for much of the last century, it contains one of the largest and least modified areas of yellow box-red gum woodland in the ACT region (ACT Government 2004). Overstorey projective foliage cover ranges from $0 \%$ to $40 \%$ with a mean of $16 \%$ (McElhinny 2005, unpubl. data). Average annual rainfall is $615 \mathrm{~mm}$, and soils are typically Yellow Chromosols and Yellow Kandosols of moderate fertility. Grazing and collection of firewood ceased in 2004 when the site was declared a nature reserve (Manning et al. 2007). Collection of firewood before 2004 was accounted for by excluding trees with either a broken limb that could not be traced to a fallen branch on the ground, or fallen branch debris containing saw or axe cuts. The relatively intact nature of this woodland provided trees with a range of sizes and crown condition.

\section{Data collection}

A representative sample of trees was selected using a technique based on the wandering quarter method (Catana 1963) (Fig. 2). This technique provided an unbiased method for sampling a population of trees with a scattered spatial distribution. In particular, the use of transects ensured the full range of aspects and topographic positions were sampled in the woodland. A random point on the boundary of Goorooyarroo Nature Reserve was selected as the start of the first transect. Subsequent transect origins were located $200 \mathrm{~m}$ from the intersection of the previous transect with the property boundary. All transects were located on either a North-South or East-West bearing.

To ensure a representative sample of tree sizes and crown conditions were collected, the sample was stratified according to 10 levels of tree diameter at breast height (dbh) and 4 levels of crown condition, giving 40 strata (Table 1). Sampling continued until there were 3-5 replicates per stratum. Only one tree per stratum was sampled from each transect

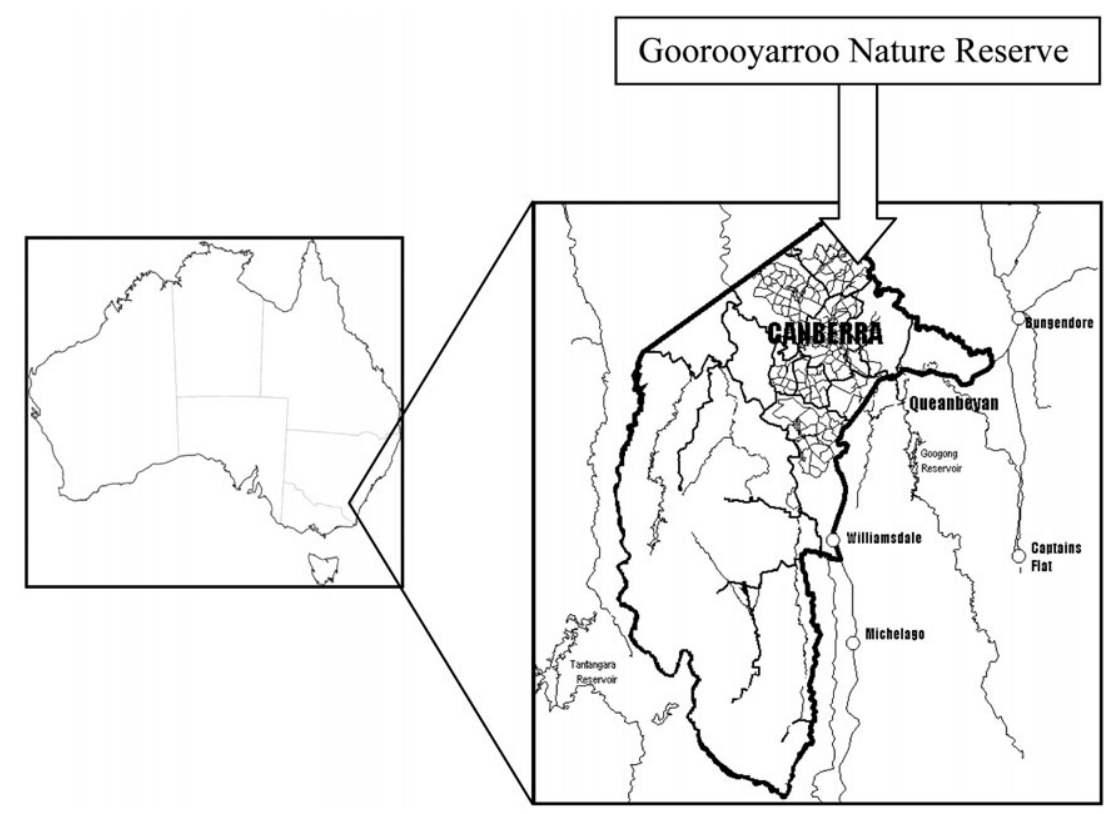

Fig. 1. Location of the study site. Goorooyarroo Nature Reserve comprises approximately 700 ha of relatively unmodified yellow box-red gum woodland. Compiled from ACT Planning and Land Authority (2008) and Geoscience Australia (2008). 
unless trees were more than $500 \mathrm{~m}$ apart. This ensured that the trees in each stratum came from a variety of locations across the study site.

For each tree sampled, the total volume of branch debris was estimated using a branch volume model developed by Killey (2008), in which;

$$
\begin{aligned}
\ln (\text { branchvolume })= & 0.352+0.862 \ln (\text { branchlength })+ \\
& 1.979 \ln (\text { basediameter })
\end{aligned}
$$

Where branchvolume is the total volume $\left(\mathrm{cm}^{3}\right)$ of all parts of the branch greater than $10 \mathrm{~cm}$ diameter, branchlength is the length of the central axis of the branch $(\mathrm{cm})$ and basediameter is the large end diameter of the branch $(\mathrm{cm})$.

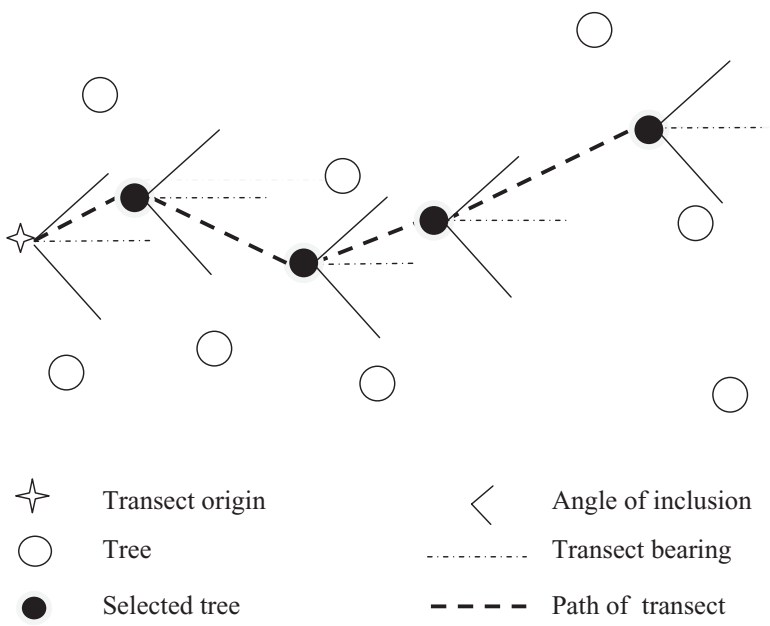

Fig. 2. The wandering quarter sampling method (Catana 1963) was used to select trees for the model of tree debris volume. Each transect origin formed the vertex of a $90^{\circ}$ angle of inclusion bisected by the transect bearing. The nearest tree within this angle of inclusion was identified and considered for inclusion in the sample. This tree then became the vertex of the subsequent angle of inclusion bisected by the same compass bearing.
Diameters were measured with callipers, or on larger branches, with a diameter tape. When diameters were measured with callipers, the geometric average of the diameters corresponding to the major and minor axes was used in volume calculations. Branch length was measured by laying a fibreglass tape along the branch from the large end to the $10-\mathrm{cm}$ diameter limit. We excluded branch fragments that had broken or decayed into pieces less than $1 \mathrm{~m}$ in length or were less than $10 \mathrm{~cm}$ in diameter.

Potential explanatory covariates of tree debris volume were recorded for inclusion in regression analysis. These covariates were: dbh, crown condition (the amount of crown present as a proportion of the estimated maximum crown extent using the four classes, $0 \%$ or dead, $<30 \%$ of maximum crown extent, $30-70 \%$ of maximum crown extent, $>70 \%$ of maximum crown extent), green crown depth (the proportion of tree height that retained green crown), topographic position (upper slope, mid slope, lower slope) and aspect (north, south, east, west, flat).

\section{Data analysis}

A two-part process was used to model tree-level branch debris, in terms of potential explanatorycovariates and their interactions. First, logistic regression was used to model the presence or absence of tree debris and then stepwise regression analysis was used to model the volume of tree debris when present. Only significant terms $(P<0.05)$ were retained in the final models. Data analysis was performed using JMP 7 statistical software (SAS Institute 2007). The performance of the tree debris volume model was checked by comparing the predicted and actual volumes of tree debris for a sample of trees quarantined from the modelling process.

Scaling up from the tree-level model to a stand-level estimate of fallen branch debris volume involved:

- Calculating the probability of debris being present for each tree in the stand;

- Calculating the predicted volume of debris for each tree in the stand;

\begin{tabular}{|c|c|c|c|c|c|c|}
\hline \multirow[b]{2}{*}{$\mathrm{DBH}$ class $(\mathrm{cm})$} & \multicolumn{5}{|c|}{ Crown condition } & \multirow[b]{2}{*}{ Total } \\
\hline & Dead & & & $30-70 \%$ & $>70 \%$ & \\
\hline $20-29.9$ & 7 & 5 & & 6 & 5 & 23 \\
\hline $30-39.9$ & 14 & 5 & & 6 & 5 & 21 \\
\hline $40-49.9$ & \begin{tabular}{|l|l|}
2 & 2 \\
\end{tabular} & 6 & & 5 & 5 & 20 \\
\hline $50-59.9$ & 2 & 3 & & 2 & 5 & 22 \\
\hline $60-69.9$ & 2 & 3 & & \begin{tabular}{|l|l|}
1 & 4 \\
\end{tabular} & 4 & 19 \\
\hline $70-79.9$ & 4 & 3 & & \begin{tabular}{l|l}
2 & 3 \\
\end{tabular} & \begin{tabular}{l|l}
1 & 6 \\
\end{tabular} & 22 \\
\hline $80-89.9$ & 6 & 4 & 1 & 3 & \begin{tabular}{|l|l|}
2 & 2 \\
\end{tabular} & 20 \\
\hline 90-99.9 & & 4 & 1 & 3 & \begin{tabular}{l|l}
1 & 4 \\
\end{tabular} & 16 \\
\hline $100-109.9$ & 3 & \begin{tabular}{l|l}
1 & 3 \\
\end{tabular} & & 5 & 3 & 18 \\
\hline$>110$ & 3 & 4 & & 4 & 3 & 19 \\
\hline Total & 44 & 50 & & 55 & 51 & 200 \\
\hline
\end{tabular}

Table 1. The sample of 200 trees stratified by DBH class and crown condition

The number of replicates in each stratum is divided into trees with debris present $(n=72)$ and trees with no debris present $(n=128)$. Some strata were rare, and so where additional data were available for a nearby stratum, they were included in the sample. DBH, diameter at breast height. 
- Multiplying the probability of debris being present by the predicted volume of debris for each tree in the stand, and summing the results to give a stand estimate of fallen branch debris volume.

To ground truth the stand-level model the volumes of fallen branch debris in six sample stands within the study site were measured using a conventional line intersect method (van Wagner 1968). Stand basal area was estimated every $100 \mathrm{~m}$ of line intersect transect using angle count sampling or basal area sweeps (Bitterlich 1947). The dbh and crown condition of each tree included in the sweep were recorded to provide an estimate of these variables for the stand. The model predictions of fallen branch debris volume were then compared with the line intersect estimates.

Three Benchmark volumes of fallen branch debris were estimated using Gibbons et al.'s (2008) predicted diameter distribution for a minimally modified yellow box-red gum stand in conjunction with the following crown condition scenarios:

- The observed distribution of crown condition in Goorooyarroo Nature Reserve;

- A distribution of crown condition, which balanced the processes of competition, stem exclusion and death in an uneven aged stand;

- A distribution of crown condition, which maximized

\section{RESULTS}

A total of 200 trees were sampled in the woodland (Table 1). Of these, 56 were yellow box, 102 were red gum and 42 were dead. Trees ranged in dbh from 21 to $138 \mathrm{~cm}$, with a mean dbh of $68.3 \mathrm{~cm}$. Seventy-two trees $(36 \%)$ had debris present and 128 had no debris. When present, the volume of debris ranged from 0.014 to $2.6 \mathrm{~m}^{3}$, with a mean volume of $0.64 \mathrm{~m}^{3}$.

\section{Logistic regression to predict the presence or absence of tree debris}

Potential explanatory variables were entered into a stepwise logistic regression analysis to predict the presence of tree debris (Table 2). Green crown depth was not significant in explaining the presence of tree debris and was removed from the model. Although aspect was not significant overall, it was retained in the model as the westerly component was significant $(P=0.017)$. The variables in the final model were $\mathrm{dbh}$, crown condition, position on slope and aspect (Eqn 1). For the 200 sample trees, the model correctly predicted debris to be absent $108 / 128$ times $(84.3 \%$ ) and correctly predicted the presence of debris 53/72 times (73.6\%).

$$
\begin{gathered}
\operatorname{Pr}(\text { Debris })=1 /(1+\exp (4.7313-0.06512 * \\
\left.\left.d b h+\text { Crown }_{i}+\text { Aspect }_{j}+\text { Position }_{k}\right)\right)
\end{gathered}
$$
fallen branch debris.

Where $\operatorname{Pr}($ Debris $)$ is the probability of the presence of tree debris; $d b h$ is diameter at breast height $(\mathrm{cm})$;

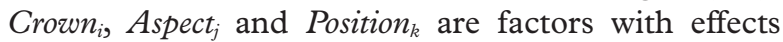
shown in Table 3.

\section{Multiple regression to predict the volume of tree debris}

Debris volume had a distribution skewed towards small volumes and was normalized using the natural logarithm transformation. A stepwise multiple regression was performed to predict $\ln$ (Debris volume) in terms of significant explanatory variables (Table 4 ). The final model was highly significant $(P<0.0001$, $\mathrm{R}^{2}=0.40$ ) and is shown in Eqn 2. The residuals of this model were approximately normally distributed with no apparent bias or heteroskedasticity.

$\ln ($ Debris volume $)=8.2948+0.0473 * d b h+$ Crown $_{i}$

Where $\ln$ (Debris volume) is the natural logarithm of tree debris $\left(\mathrm{m}^{3}\right)$; $d b h$ is diameter at breast height $(\mathrm{cm})$; Crown $_{i}$ is a factor with effects shown in Table 5.

Table 2. Significance levels for effects in logistic regression models to predict the presence or absence of tree debris for a sample of 200 trees

\begin{tabular}{lcc}
\hline & 5 Variable model & 4 Variable model \\
\cline { 2 - 3 } & \multicolumn{2}{c}{$P$ value } \\
\hline DBH (cm) & $<0.0001$ & $<0.0001$ \\
Position on slope & 0.0009 & 0.001 \\
Crown condition & 0.028 & $<0.0001$ \\
Aspect & 0.132 & 0.128 \\
(Aspect-Westerly) & $(0.017)$ & $(0.017)$ \\
Green crown depth & 0.60785 & \\
\hline
\end{tabular}

$\mathrm{DBH}$, diameter at breast height.

Table 3. Effects corresponding to the different levels of the categorical variables Crown ${ }_{i}$, Aspect ${ }_{j}$ and Position $_{k}$ in the model to predict the presence of tree debris

\begin{tabular}{llr}
\hline Variable & Level & Effect \\
\hline Crown & $0 \%$ (dead) & 0 \\
& $<30 \%$ & 0.0909 \\
& $30-70 \%$ & 1.6136 \\
& $>70 \%$ & 2.9505 \\
Aspect & North & -0.5203 \\
& South & -0.3835 \\
& East & 0.7991 \\
& West & -1.0528 \\
Position & Flat & 1.1576 \\
& Upper-slope & -0.9346 \\
& Mid-slope & -0.2825 \\
& Lower-slope & 1.2171 \\
\hline
\end{tabular}


Table 4. Significance levels for effects in multiple regression models to predict $\ln$ (debris volume) for a sample of 72 trees

\begin{tabular}{|c|c|c|c|c|c|}
\hline & $\begin{array}{l}6 \text { Variables } \\
\left(\mathrm{R}^{2}=0.54\right)\end{array}$ & $\begin{array}{l}5 \text { Variables } \\
\left(\mathrm{R}^{2}=0.53\right)\end{array}$ & $\begin{array}{l}4 \text { Variables } \\
\left(\mathrm{R}^{2}=0.50\right)\end{array}$ & $\begin{array}{l}3 \text { Variables } \\
\left(\mathrm{R}^{2}=0.47\right)\end{array}$ & $\begin{array}{l}2 \text { Variables } \\
\left(\mathrm{R}^{2}=0.40\right)\end{array}$ \\
\hline & \multicolumn{5}{|c|}{$P$ value } \\
\hline $\mathrm{DBH}$ & 0.0003 & 0.0002 & $<0.0001$ & $<0.0001$ & $<0.0001$ \\
\hline Crown condition & 0.166 & 0.160 & 0.054 & 0.097 & 0.049 \\
\hline Aspect & 0.165 & 0.110 & 0.208 & 0.157 & \\
\hline $\mathrm{DBH}^{\star}$ crown condition & 0.432 & 0.353 & & & \\
\hline Position on slope & 0.851 & & & & \\
\hline
\end{tabular}

$\mathrm{DBH}$, diameter at breast height. *interaction term.

Table 5. Effects corresponding to the different levels of the categorical variable Crown $_{i}$, in the model to predict $\ln \left(\right.$ Debris $^{2}$ volume)

\begin{tabular}{lll}
\hline Variable & Level & Effect \\
\hline Crown & $0 \%($ dead) & 0 \\
& $<30 \%$ & 0.6953 \\
& $30-70 \%$ & 0.1715 \\
& $>70 \%$ & -0.8733 \\
\hline
\end{tabular}

A regression of measured against predicted $\ln$ (Debris volume) for 12 trees quarantined from the modelling process demonstrated that the model was unbiased (Fig. 3).

\section{Model sensitivity}

Model sensitivity to tree size and crown condition indicated that larger trees with poorer crown condition were more likely to have debris present (Fig. 4) and to produce larger volumes of debris than smaller trees with healthier crowns (Fig. 5). Model predictions indicated a $100-\mathrm{cm}$ dbh tree was 10 times more likely to produce debris than a $50-\mathrm{cm}$ dbh tree, and if debris was present a $100-\mathrm{cm}$ dbh tree produced approximately 10 times the volume of branch debris produced by a $50-\mathrm{cm}$ dbh tree (Table 6 ). These results highlight the key role of large trees in producing fallen branch debris.

\section{Stand-level estimates of fallen branch debris volume}

The measured volume of coarse woody debris in six different stands was compared with the predicted volume of branch debris for each stand (Fig. 6). The measured volumes were based on field sampling of each stand using the line intersect technique, while the predicted volumes were estimated by applying the tree debris model to the observed diameter and crown condition distribution for each stand. A regression of

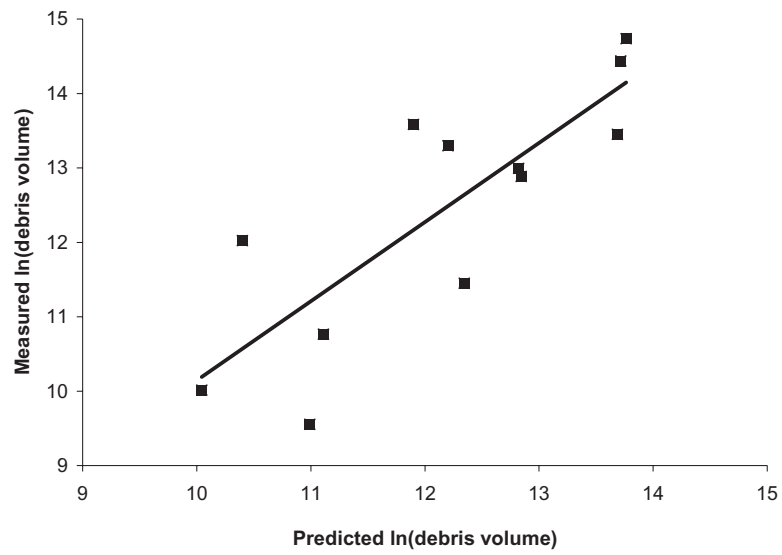

Fig. 3. Regression of measured $\ln$ (debris volume) against predicted $\ln$ (debris volume) for the 12 trees quarantined from the modelling process. Measured $\ln$ (debris volume $)=-0.499+1.06^{\star}$ Predicted $\ln ($ debris volume $)$ $\left(\mathrm{R}^{2}=0.67\right)$. The intercept was not significantly different from 0 , and the slope was not significantly different from 1 .

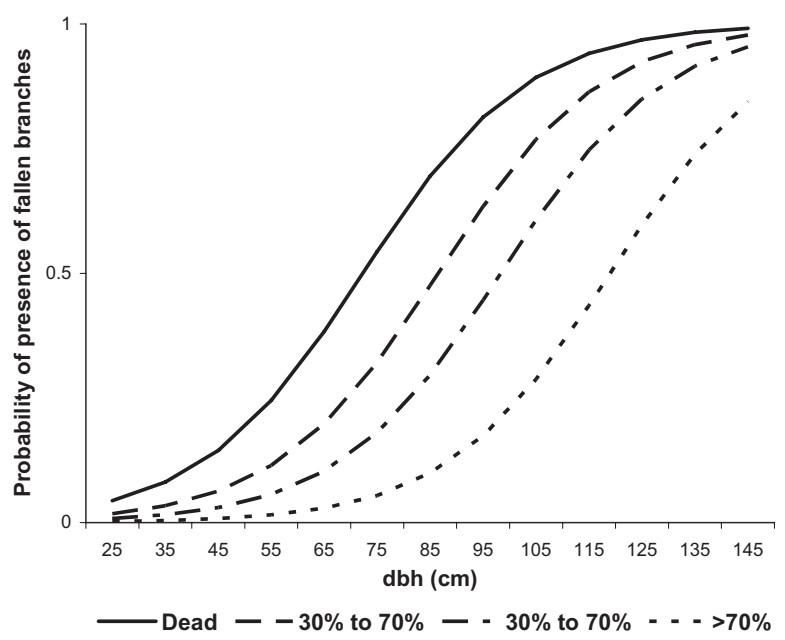

Fig. 4. Predicted probability of debris being present under a tree according to tree $\mathrm{dbh}$ and crown condition (the amount of crown present as a proportion of the estimated maximum crown extent using the four classes, $0 \%$ or dead, $<30 \%$ of maximum crown extent, $30-70 \%$ of maximum crown extent, $>70 \%$ of maximum crown extent). Aspect and position on slope were excluded from the model. dbh, diameter at breast height.

doi:10.1111/j.1442-9993.2010.02107.x 


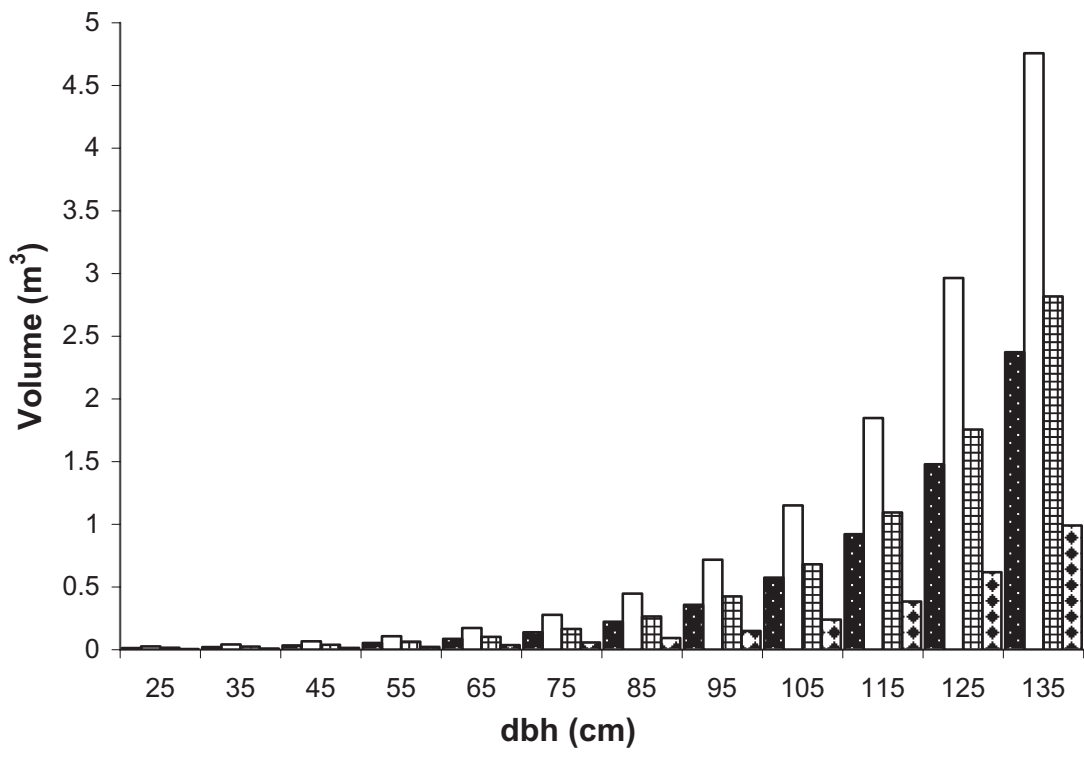

Dead $\square<30 \%$ 田 $30 \%$ to $70 \%$ D $70 \%$

Fig. 5. The predicted volume of tree debris (when present) according to dbh and crown condition (the amount of crown present as a proportion of the estimated maximum crown extent using the four classes, $0 \%$ or dead, $<30 \%$ of maximum crown extent, $30-70 \%$ of maximum crown extent, $>70 \%$ of maximum crown extent). The effects of aspect and position on slope have been excluded from the model. dbh, diameter at breast height.

Table 6. The estimated probability of debris being present and volume of tree debris (when present) for trees of $50 \mathrm{~cm}$ and $100 \mathrm{~cm} \mathrm{DBH}$

\begin{tabular}{|c|c|c|c|c|}
\hline \multirow[b]{3}{*}{ Crown condition } & \multicolumn{4}{|c|}{$\mathrm{DBH}(\mathrm{cm})$} \\
\hline & \multicolumn{2}{|r|}{50} & \multicolumn{2}{|r|}{100} \\
\hline & $\mathrm{m}^{3}$ & Probability debris present & $\mathrm{m}^{3}$ & Probability debris present \\
\hline Dead & 0.043 & 0.19 & 0.45 & 0.86 \\
\hline$<30 \%$ & 0.085 & 0.08 & 0.91 & 0.71 \\
\hline $30-70 \%$ & 0.051 & 0.04 & 0.54 & 0.54 \\
\hline$>70 \%$ & 0.018 & 0.01 & 0.19 & 0.24 \\
\hline
\end{tabular}

The effects of aspect and topographic position have been excluded from the model. $\mathrm{DBH}$, diameter at breast height.

measured against predicted stand-level debris for the six stands demonstrated that the model was unbiased, although there was a large amount of variation in debris volume between the six stands (Fig. 6).

The model of tree debris was then applied to the dbh distribution published by Gibbons et al. (2008) for a minimally modified yellow box-red gum grassy woodland. As there were no published estimates of the distribution of crown condition in a minimally modified stand, the following three crown condition scenarios were constructed (Table 7):

- The average crown condition distribution observed in the study area;

- A balanced crown condition distribution to represent the processes of competition, stem exclusion and death in an uneven aged stand (Oliver \& Larson 1996);
- A crown condition distribution that allocated the majority of the stand to the poorer crown condition classes to estimate the maximum volume of fallen branch debris that the model would predict.

As the Gibbons et al. (2008) dbh distribution only included live trees, a method of estimating the number and distribution of dead trees in a stand was also required. For the first scenario, the observed distribution of dead trees in the study area was used. For the other two scenarios, half the number of trees in the $<30 \%$ crown condition class were added to the stand as dead trees, reflecting expected mortality from trees in this crown condition class. For all scenarios, aspect and topographic position were excluded from the model on the assumption that these variables are evenly distributed across the landscape. The three scenarios produced estimates of fallen branch debris 
volume in close agreement to the Gibbons et al. (2008) estimate for these woodlands (Table 8).

\section{DISCUSSION}

\section{A dynamic model}

The volume of fallen branch debris at any point in time is the balance between inputs from branch shed-

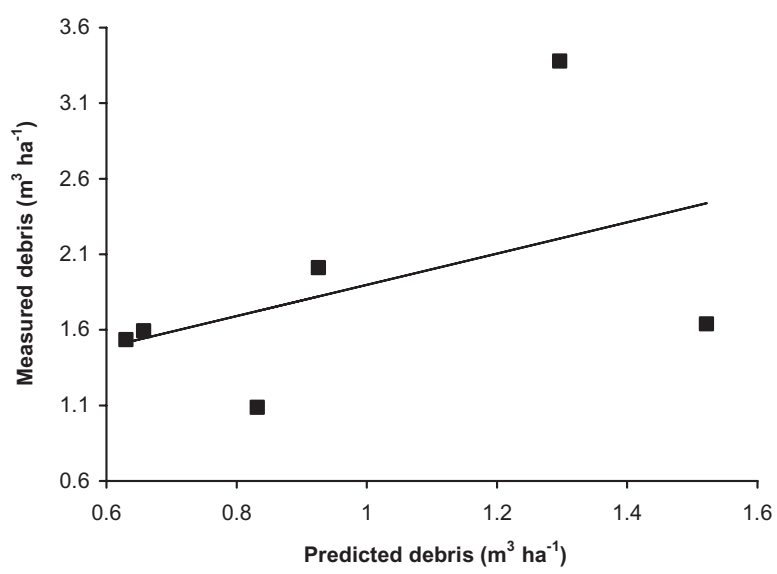

Fig. 6. Regression of measured stand debris volume $\left(\mathrm{m}^{3} \mathrm{ha}^{-1}\right)$ against predicted stand debris volume for 6 stands $\left(\mathrm{m}^{3} \mathrm{ha}^{-1}\right)$. Measured stand debris volume $=0.863+$ $1.03^{\star}$ Predicted stand debris volume $\left(\mathrm{R}^{2}=0.22\right)$. The intercept was not significantly different from 0 , and the slope was not significantly different from 1 . ding, and outputs resulting from decay and fire (Harmon et al. 1986; Mac Nally et al. 2002a). Our methodology incorporated these dynamic processes by sampling across the range of tree size and crown conditions. We assumed that tree size was a measure of branch debris inputs and the length of time over which these occurred, and that crown condition captured large branch shedding events because of senescence and disturbance agents. We also assumed that the volume of branch debris present under each sample tree incorporated past losses because of decay and fire. The volume of fallen branches under each tree sampled was therefore the sum of input and output processes up to that point in time. These dynamic processes were then reflected in our model via parameters describing diameter and crown condition distribution. Unlike the dynamic model of coarse woody debris production published by West et al. (2008) our approach did not therefore require growth models or decay constants to predict the production of coarse woody debris.

The spatial and temporal heterogeneity of coarse woody debris requires benchmarks that incorporate a range of variability. Our models can estimate a benchmark range for fallen branch debris loads if the variability in tree diameter and crown condition is known. For example, our models could be applied to immature or mature stands, or stands that have experienced a severe disturbance. These modelled estimates are therefore fundamentally different to the estimates of Manning et al. (2007) and Gibbons et al. (2008),

Table 7. The 3 crown condition distribution scenarios allocated to the benchmark dbh distribution published by Gibbons et al. (2008)

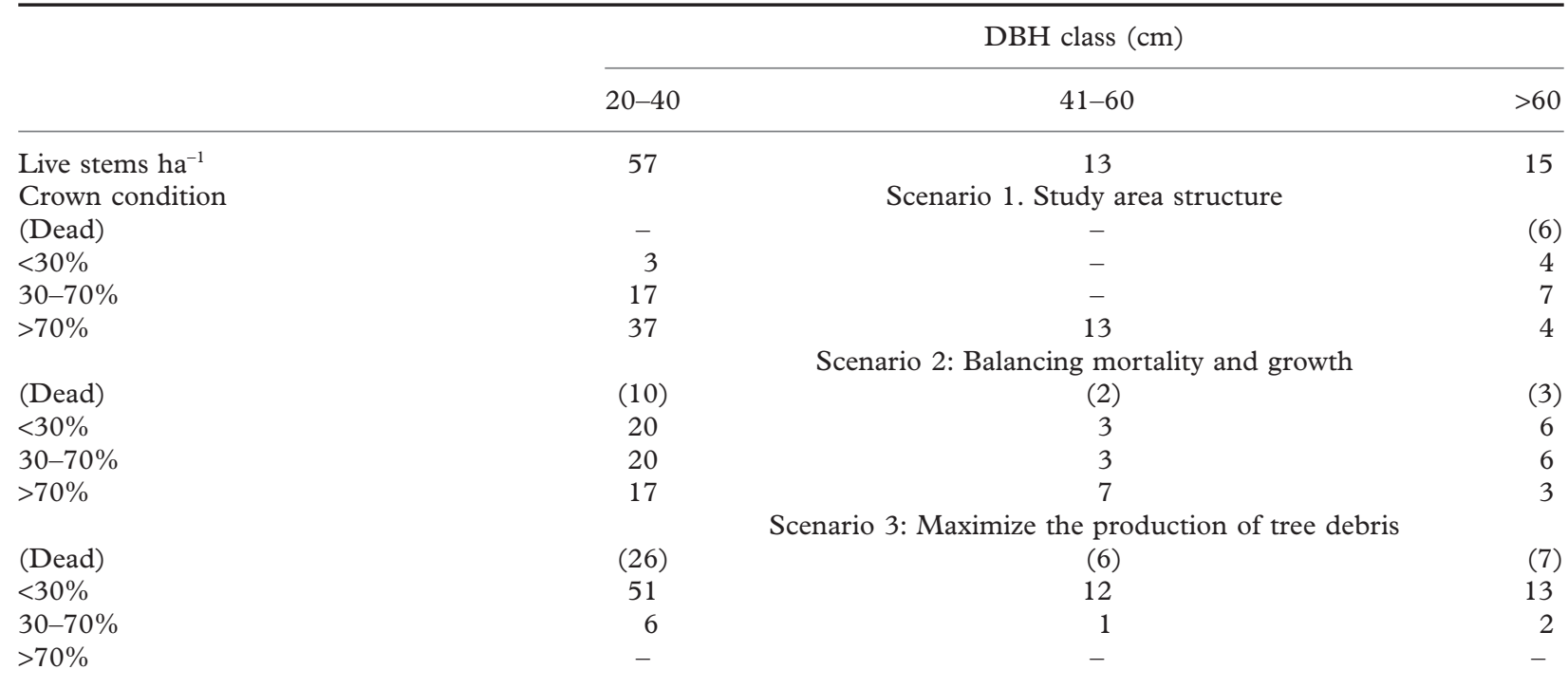

For each scenario, the number of dead stems (n) was additional to the number of live stems per hectare. For Scenario 1, the number of dead trees reflected the proportion of dead trees observed in the study area. For Scenarios 2 and 3 , the number of dead trees was half the number of stems in the $<30 \%$ crown condition class. 


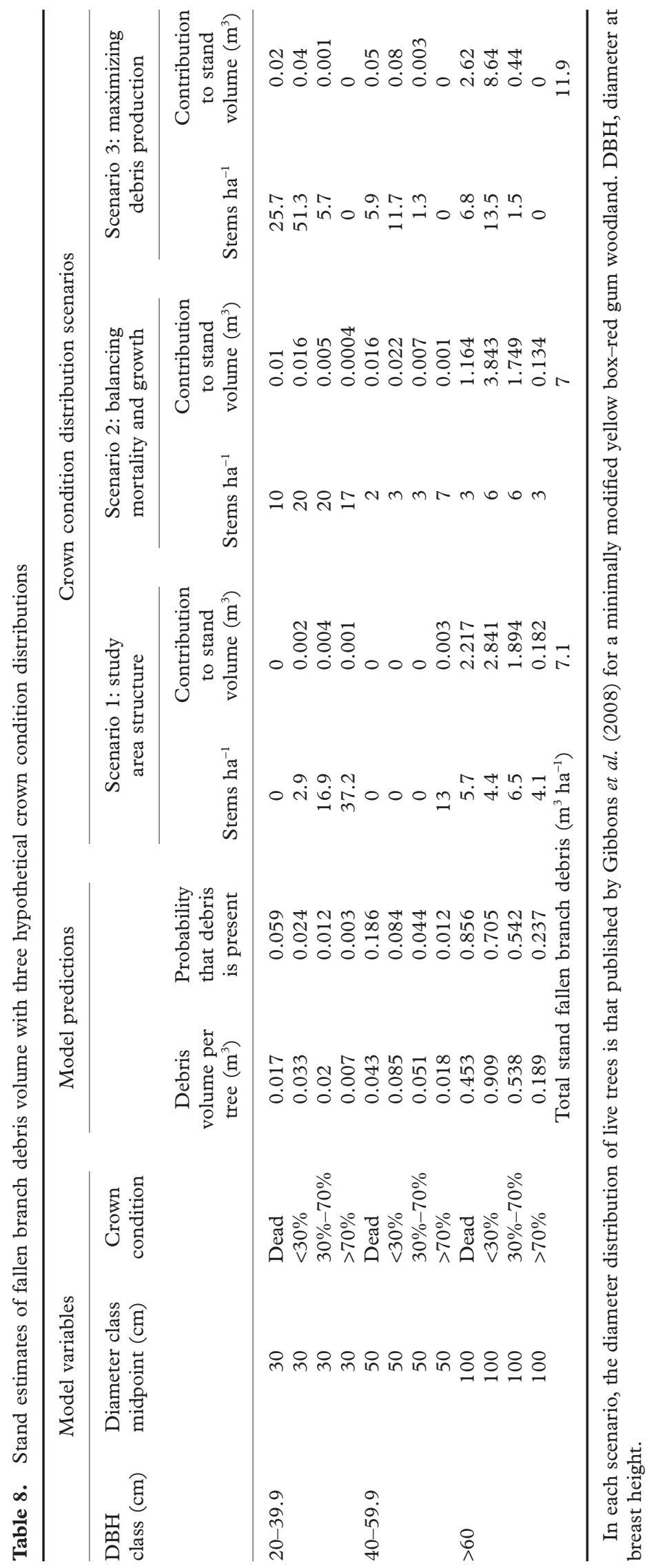


whose methodologies were based on point in time measurements of coarse woody debris loads. Such measurements are unable to estimate the range of variability necessary to reflect the stochastic nature of coarse woody debris production (White \& Walker 1997).

\section{Tree-level models}

At the tree-level we found a strong relationship between the volume of branch debris and tree size. This is consistent with the growth habits of eucalypts. Larger eucalypt trees are more likely to shed branches through overextension, and because of their greater age are more likely to have been affected by disturbance events that produce fallen branches such as drought, fire, wind or attack by decay organisms (Jacobs 1955). In addition, larger trees carry larger branches, which will contain more debris compared with branches from smaller trees. These results are supported by Harmon et al. (1986) and Harmon and Hua (1991) who suggest that the stock of coarse woody debris is positively correlated to living biomass. In our model, $\ln$ (debris volume) was proportional to $\mathrm{dbh}$ indicating large trees produced a disproportionate stock of debris for their size.

Our model also identified crown condition, aspect and topographic position as significant variables influencing the production of coarse woody debris, with trees of poorer crown condition, on north to westerly aspects and located on upper slopes most likely to produce branch debris. Crown condition is intuitively related to the presence of fallen branches as the shedding of branches produces debris and reduces crown cover. The prevailing wind direction for our study site was north-westerly (Bureau of Meterology 2008), and trees exposed to these winds are more likely to produce debris compared with protected easterly and southerly aspects. This effect is likely to be more pronounced on upper slopes (Harmon et al. 1986). In addition, trees on upper slopes, or west and northerly aspects are more likely to suffer from water stress, which may also increase the probability of branches being shed.

The relationship between topographic position and the production of coarse woody debris has been investigated by other authors. Webster and Jenkins (2005) found increased elevation was associated with higher coarse woody debris loads in Appalachian forests. However, they argued that this might be explained by the accessibility of lower slopes for firewood collection. This was unlikely in our study because we excluded any trees with evidence of debris removal. Wilcke et al. (2005) found no relationship between coarse woody debris loads and topographic position in a montane forest in Ecuador. However, this result may reflect a more continuous canopy that would have ameliorated the exposure of individual trees to damaging winds. The effect of wind on isolated woodland trees on upper slopes is likely to be very different.

Although our models identified dead trees as important producers of branch debris, the greatest inputs of branch debris were from live trees with poor crown condition (Fig. 6). This result confirms the dynamic nature of fallen branch debris. Live trees, particularly mature and senescing trees, have crowns that are actively growing and contracting (Jacobs 1955). These trees shed an ongoing supply of branches to replenish their stock of debris. Dead trees, however, have a limited supply of branches that can contribute to the volume of tree debris, which will, therefore, gradually decline as debris decays.

\section{Stand-level model}

The stand-level benchmark volume of fallen branch debris predicted by our models $\left(7.0 \mathrm{~m}^{3} \mathrm{ha}^{-1}\right)$ was in close agreement with the estimate published by Gibbons et al. (2008) of $8.2 \pm 2.6 \mathrm{~m}^{3} \mathrm{ha}^{-1}$. Manning et al.'s (2007) estimate of $19.3 \mathrm{~m}^{3} \mathrm{ha}^{-1}$ of debris for these woodlands was more than twice that predicted by our models. Altering the distribution of crown condition in our models to maximize the volume of fallen branch debris returned a predicted volume of $11.9 \mathrm{~m}^{3} \mathrm{ha}^{-1}$, which was still less than Manning et al.'s estimate. By deliberately biasing sampling towards areas where coarse woody debris was present, Manning et al. (2007) may have overestimated benchmark loads. However, our models did not include fallen boles, which can also contribute to coarse woody debris loads; although in eucalypt woodlands, dead trees can remain standing for long periods of time, gradually shedding branches (Moloney et al. 2002). If the samples selected by Manning et al. (2007) contained a number of fallen boles, these would have considerably increased their final estimate; for example one large fallen bole $1 \mathrm{~m}$ in diameter and $10 \mathrm{~m}$ long may contain $10 \mathrm{~m}^{3}$ of coarse woody debris. Further research is therefore required to quantify the distribution of fallen boles in these woodlands, and their relative contribution to coarse woody debris loads.

Our results should also be treated cautiously because our models were limited to data from a single large (700 ha) woodland, although we sampled this across the full range of aspect and topographic positions. Manning et al. (2007) were also limited to data from just two contiguous sites, whereas Gibbons et al. (2008) sampled a range of woodland sites. Further research is therefore needed to incorporate some of the variation expected from sites with different disturbance and land-use histories into our models. 


\section{Management of remnant woodlands}

Our models predict that the bulk of fallen branch debris is produced by large $(>100 \mathrm{~cm} \mathrm{dbh})$ senescing trees (Fig. 5, Table 6). As yellow box trees can live for more than 400 years (Banks 1997), the time required for individuals to reach this size and growth stage could exceed 200 years. Without intervention it could therefore take several hundred years for remnant and regenerating yellow box-red gum woodlands to accumulate coarse woody debris approaching benchmark loads because inputs are driven by branches shed from large senescing trees. Time lags for the accumulation of coarse woody debris to levels found in mature or 'old growth' stands have been reported for a number of vegetation communities. These estimates range from 70 years for tropical forests (Dewalt et al. 2003) to more than 500 years for temperate coniferous forests (Spies et al. 1988). On sites revegetated with eucalypt species in Victoria, Vesk et al. (2008) found that coarse woody debris loads took 150 years to reach the levels found on unmodified sites.

Our results therefore support Manning et al.'s (2007) assertion that on its own reservation of remnant woodlands is unlikely to arrest a decline in coarse woody debris dependent species or processes in the short-to-medium term. To meet more immediate biodiversity and conservation needs, it will be necessary to augment existing coarse woody debris stocks (Mac Nally \& Horrocks 2007; Manning et al. 2007). However, such actions are only stop gaps, and management strategies that facilitate the onsite production of coarse woody debris will be required to maintain longer-term supplies of this resource.

Our results demonstrate that large remnant trees have an enhanced capacity for the production of fallen branch debris compared with smaller regrowth trees. The retention of these large senescent, dying and dead trees within remnant woodlands is therefore central to maintaining fallen branch debris stocks in the short-to-medium term. In the longterm, current regrowth may also contribute to fallen may slow the growth of woodland trees, inhibiting their progression to senescence (Bauhus et al. 2002). It may also alter the crown structure of trees, reducing the proportion of biomass allocated to branches (Henskens et al. 2001). Thinning dense stands of regrowth may therefore have a number of benefits, including the immediate provision of woody debris if thinnings are left onsite, the promotion of faster growth on retained trees facilitating their progression to senescence, and the encouragement of open-grown crown structures with larger, heavier branches (Meagher 2002; Vesk et al. 2008). branch debris stocks. However, dense regeneration

\section{ACKNOWLEDGEMENTS}

We are grateful for the advice and encouragement of Adrian Manning and Cris Brack, and for assistance with data collection from Sarit Kaserzon, Sarah Goldin and Jeremy Dufour. Access to the study site was granted by Territory and Municipal Services, ACT Government. Comments by three anonymous referees improved an earlier version of this manuscript.

\section{REFERENCES}

ACT Government (2004) Woodlands for Wildlife: ACT Lowland Woodland Conservation Strategy. Action Plan No. 27. Environment ACT, Canberra.

ACT Planning and Land Authority (2008) Actmap. ACT Government, Canberra. [Cited 3 May 2008.] Available from URL: http://www.actmapi.act.gov.au/framesetup.asp

Banks J. C. G. (1997) Tree ages and ageing in yellow box. In: The Coming of Age - Forest Age $\mathcal{E}$ Heritage Values (ed. J. Dargavel) pp. 17-28. Environment Australia, Canberra.

Barton P. S., Manning A. D., Lindenmayer D. B. \& Cunningham S. A. (2009) Conserving ground-dwelling beetles in an endangered woodland community: multi-scale habitat effects on assemblage diversity. Biol. Conserv. 142, 1701-9.

Bate L. J., Torgersen T. R., Wisdom M. J. \& Garton E. O. (2004) Performance of sampling methods to estimate log characteristics for wildlife. For. Ecol. Manage. 199, 83-102.

Bauhus J., McElhinny C. \& Alcorn P. (2002) Stand structure and tree growth in uneven-aged spotted gum (Corymbia maculata) forests: some implications for management. Forry 75, 451-6.

Beadle N. C. W. (1981) The Vegetation of Australia. Gustav Fischer Verlag, Stuttgart.

Bitterlich W. (1947) The angle count method. Allg. Forst. Fagdztg. 58, 94-6.

Bowker M. A. (2007) Biological soil crust rehabilitation in theory and practice: an underexploited opportunity. Restor. Ecol. 15, 13-23.

Bureau of Meterology (2008) Climate Statistics for Australian Locations (Canberra Airport). Bureau of Meterology, Commonwealth of Australia, Canberra. [Cited 3 May 2008.] Available from URL: http://www.bom.gov.au/climate/ averages/tables/cw_070014.shtml

Catana A. (1963) The wandering quarter method of estimating population density. Ecology 44, 349-60.

de Chantal M. \& Granström A. (2007) Aggregations of dead wood after wildfire act as browsing refugia for seedlings of Populus tremula and Salix caprea. For. Ecol. Manage. 250, 3-8.

Davidson N. J., Close D. C., Battaglia M. et al. (2007) Eucalypt health and agricultural land management within bushland remnants in the Midlands of Tasmania, Australia. Biol. Conserv. 139, 439-46.

Debeljak M. (2006) Coarse woody debris in virgin and managed forest. Ecol. Indic. 6, 733-42.

Department of the Environment and Water Resources (2007) Australia's Native Vegetation: A Summary of Australia's Major Vegetation Groups, 2007. Department of the Environment and Water Resources, Commonwealth of Australia, Canberra.

Department of the Environment Water Heritage and the Arts (2008) White Box-Yellow Box-Blakely's Red Gum Grassy

doi:10.1111/j.1442-9993.2010.02107.x
(C) 2010 The Authors

Journal compilation (C) 2010 Ecological Society of Australia 
Woodland and Derived Native Grassland. Department of the Environment, Water, Heritage and the Arts, Australian Government, Canberra. [Cited 14 April 2008.] Available from URL: http://www.environment.gov.au/cgi-bin/sprat/public/ publicshowcommunity.pl?id $=43 \&$ status $=$ Critically $\% 20$ Endangered

DeWalt S. J., Maliakal S. K. \& Denslow J. S. (2003) Changes in vegetation structure and composition along a tropical forest chronosequence: implications for wildlife. For. Ecol. Manage. 182, 139-51.

Doerr V. A., Doerr E. D. \& Jenkins S. H. (2006) Habitat selection in two Australasian treecreepers: what cues should they use? Emu 106, 93-103.

Driscoll D., Milkovits G. \& Freudenberger D. (2000) Impact and Use of Firewood in Australia. CSIRO Sustainable Ecosystems, Canberra.

Geoscience Australia (2008) Basic Outline of Australia. Commonwealth of Australia, Canberra. [Cited 3 May 2008.] Available from URL: http://www.ga.gov.au

Gibbons P., Briggs S., Ayers D. et al. (2008) Quantifying reference conditions in modified landscapes. Biol. Conserv. 141, 2483-93.

Grove S. J. \& Meggs J. (2003) Coarse woody debris, biodiversity and management: a review with particular reference to Tasmanian wet eucalypt forests. Aust. For. 66, 247-57.

Hagan J. \& Grove S. (1999) Coarse woody debris: humans and nature competing for trees. F. For. 97, 6-11.

Harmon M. \& Hua C. (1991) Coarse woody debris dynamics in two old-growth ecosystems. BioScience 41, 604-11.

Harmon M., Franklin J., Swanson F. et al. (1986) Ecology of coarse woody debris in temperate ecosystems. Adv. Ecol. Res. 15, 133-302.

Henskens F., Battaglia M., Cherry M. \& Beadle C. (2001) Physiological basis of spacing effects on tree growth and form in Eucalyptus globulus. Trees Struct. Funct. 15, 365-77.

Jacobs M. (1955) Growth Habits of the Eucalypts. Forestry and Timber Bureau, Department of the Interior, Canberra.

James K. R., Haritos N. \& Ades P. K. (2006) Mechanical stability of trees under dynamic loads. Am. F. Bot. 93, 1522-30.

Keane P., Kile G., Podger F. \& Brown B., eds (2000) Diseases and Pathogens of Eucalypts. CSIRO Publishing, Collingwood.

Killey P. (2008) Modelling the volume of fallen branch debris in yellow box - red gum woodland. (Honours thesis). Australian National University, Canberra.

Landsberg J. (2000) Status of temperate woodlands in the Australian Capital Territory Region. In: Temperate Eucalypt Woodlands in Australia (eds R. Hobbs \& C. Yates) pp. 32-44. Surrey Beatty and Sons, Chipping Norton.

Lester R., Wright W. \& Jones-Lennon M. (2006) Determining target loads of large and small wood for stream rehabilitation in high-rainfall agricultural regions of Victoria, Australia. Ecol. Eng. 28, 71-8.

Lunt I. (2002) Grazed, burnt and cleared: how ecologists have studied century-scale vegetation changes in Australia. Aust. f. Bot. 50, 391-407.

McElhinny C., Gibbons P. \& Brack C. (2006) An objective and quantitative methodology for constructing an index of stand structural complexity. For. Ecol. Manage. 235, 54-71.

Mackensen J., Bauhus J. \& Webber E. (2003) Decomposition rates of coarse woody debris: a review with particular emphasis on Australian tree species. Aust. F. Bot. 51, 2737.

Mac Nally R. \& Horrocks G. (2007) Inducing whole-assemblage change by experimental manipulation of habitat structure. $\mathcal{F}$. Anim. Ecol. 76, 643-50.
Mac Nally R., Parkinson A., Horrocks G., Conole L. \& Tzaros C. (2001) Relationships between terrestrial vertebrate diversity, abundance and availability of coarse woody debris on southeastern Australian floodplains. Biol. Conserv. 99, 191-205.

Mac Nally R., Ballinger A. \& Horrocks G. (2002a) Habitat change in River red gum floodplains: depletion of fallen timber and impacts on biodiversity. Vic. Natur. 119, 10713.

Mac Nally R., Parkinson A., Horrocks G. \& Young M. (2002b) Current loads of coarse woody debris on southeastern australian floodplains: evaluation of change and implications for restoration. Restor. Ecol. 10, 627-35.

Manning A., Lindenmayer D. \& Cunningham R. (2007) A study of coarse woody debris volumes in two box-gum grassy woodland reserves in the Australian Capital Territory. Ecol. Manage. Restor. 8, 221-4.

Martin T. \& Green J. (2002) Wildlife and core conservation areas. In: Managing and Conserving Grassy Woodlands (eds S. McIntyre, J. Mcivor \& K. Heard) pp. 111-42. CSIRO Publishing, Collingwood.

Martin W. K., Eyears-Chaddock M., Wilson B. R. \& Lemon J. (2004) The value of habitat reconstruction to birds at Gunnedah, New South Wales. Emи 104, 177-89.

Maser C., Cline S., Cromack K., Trappe J. \& Hansen E. (1988) What we know about large trees that fall to the forest floor. In: From the Forest to the Sea: A Story of Fallen Trees (eds C. Maser, R. Tarrant, J. Trappe \& J. Franklin) pp. 25-45. US Department of Agriculture, Forest Service, Portland.

Meagher D. (2002) Victoria's box-ironbark forests and woodlands. Trees Nat. Resour. 44, 19-22.

Moloney D., Wormington K. \& DeStefano S. (2002) Stag retention and use by arboreal marsupials in eucalypt forests in Southeast Queensland, Australia: implications for management. In: Proceedings of the Symposium on the Ecology and Management of Dead Wood in Western Forests, Gen. Tech. Rep. PSW-GTR-181 (eds W. Laudenslayer, P. Shea, B. Valentine, P. Weatherspoon \& T. Lisle) pp. 347-55. U.S. Department of Agriculture, Forest Service, Pacific Southwest Research Station, Albany.

NSW Scientific Committee (2002) White Box Yellow Box Blakely's Red Gum Woodland - Endangered Ecological Community Listing. Department of Environment and Climate Change, New South Wales Government, Sydney. [Cited 8 April 2008.] Available from URL: http://www.environment.nsw. gov.au/determinations/BoxgumWoodlandEndComListing. htm

Oliver C. \& Larson B. (1996) Forest Stand Dynamics. Wiley, New York.

Oliver I., Smith P. L., Lunt I. \& Parkes D. (2002) Pre-1750 vegetation, naturalness and vegetation condition: what are the implications for biodiversity conservation? Ecol. Manage. Restor. 3, 176-8.

Parkes D., Newell G. \& Cheal D. (2003) Assessing the quality of native vegetation: the 'habitat hectares' approach. Ecol. Manage. Restor. 4 (Suppl.), S29-38.

Pook E. W. (1985) Canopy dynamics of Eucalyptus maculata Hook. III Effects of drought. Aust. F. Bot. 33, 65-79.

Prober S., Lunt I. \& Thiele K. (2002) Determining reference conditions for management and restoration of temperate grassy woodlands: relationships among trees, topsoils and understorey flora in little-grazed remnants. Aust. F. Bot. 50, 687-97.

Prober S. M. \& Thiele K. R. (2005) Restoring Australia's temperate grasslands and grassy woodlands: integrating function and diversity. Ecol. Manage. Restor. 6, 16-27. 
SAS Institute (2007) FMP Statistical Discovery Software. SAS Institute, Cary.

Smith A. P., Wellham G. S. \& Green S. W. (1989) Seasonal foraging activity and microhabitat selection by echidnas (Tachyglossus aculeatus) on the New England Tablelands. Aust. F. Ecol. 14, 457-66.

Spies T., Franklin J. F. \& Thomas T. (1988) Coarse woody debris in douglas-fir forests of Western Oregon and Washington. Ecology 69, 1689-702.

Stevens V. (1997) The Ecological Role of Coarse Woody Debris: An Overview of the Ecological Importance of CWD in BC Forests. Ministry of Forests Research Program, Victoria.

Tinker D. B. \& Knight D. H. (2001) Temporal and spatial dynamics of coarse woody debris in harvested and unharvested Lodgepole pine forests. Ecol. Model. 141, 125-49.

Tongway D. J. \& Ludwig J. A. (1996) Rehabilitation of semiarid landscapes in Australia. I. Restoring productive soil patches. Restor. Ecol. 4, 388-97.

Vanderwel M. C., Malcolm J. R. \& Smith S. M. (2006) An integrated model for snag and downed woody debris decay class transitions. For. Ecol. Manage. 234, 48-59.

Vesk P. A., Nolan R., Thomson J. R., Dorrough J.W. \& Mac Nally R. (2008) Time lags in provision of habitat resources through revegetation. Biol. Conserv. 141, 174-86.

van Wagner C. (1968) The line intersect method in forest fuel sampling. For. Sci. 14, 20-6.

Wall J. (2000) Fuelwood in Australia: impacts and opportunities. In: Temperate Eucalypt Woodlands in Australia: Biology, Conservation, Management and Restoration (eds R. J. Hobbs \& C. J. Yates) pp. 372-81. Surrey Beatty \& Sons, Chipping Norton.
Webster C. R. \& Jenkins M. A. (2005) Coarse woody debris dynamics in the southern Appalachians as affected by topographic position and anthropogenic disturbance history. For. Ecol. Manage. 217, 319-30.

West P. W., Cawsey E. M., Stol J. \& Freudenberger D. (2008) Firewood harvest from forests of the Murray-Darling Basin, Australia. Part 1: long-term, sustainable supply available from native forests. Biomass. Bioenerg. 32, 1206-19.

White P. S. \& Walker J. (1997) Approximating nature's variation: selecting and using reference information in restoration ecology. Restor. Ecol. 5, 338-49.

Wilcke W., Hess T., Bengel C., Homeier J., Valarezo C. \& Zech W. (2005) Coarse woody debris in a montane forest in Ecuador: mass, C and nutrient stock, and turnover. For. Ecol. Manage. 205, 139-47.

Woldendorp G. \& Keenan R. J. (2005) Coarse woody debris in Australian forest ecosystems: a review. Austral Ecol. 30, 83443.

Woldendorp G., Spencer R., Keenan R. \& Barry S. (2002) An Analysis of Sampling Methods for Coarse Woody Debris in Australian Forest Ecosystems. Bureau of Rural Sciences, Canberra.

Woldendorp G., Keenan R. J., Barry S. \& Spencer R. D. (2004) Analysis of sampling methods for coarse woody debris. For. Ecol. Manage. 198, 133-48.

Yates C. \& Hobbs R. (1997) Temperate Eucalypt Woodlands: A review of their status, processes threatening their persistence and techniques for restoration. Aust. F. Bot. 45, 949-73. 